\title{
Sugar mill effluent treatment using fixed film algal photo-bioreactor and reuse of treated water
}

\author{
Dr. Amol B. Deshmane *, Vishal P. Jadhav ${ }^{* *}$, Dr. Vikram S. Ghole ${ }^{* * *}$ \\ * Department of Environmental Sciences, Vasantdada Sugar Institute, Pune, Maharashtra 412307 India \\ ** Department of Environmental Sciences, Vasantdada Sugar Institute, Pune, Maharashtra \\ *** Executive Director, Lokmanya Medical Research Center, Chinchwad, Pune 411033 \\ DOI: 10.29322/IJSRP.12.01.2022.p12167 \\ http://dx.doi.org/10.29322/IJSRP.12.01.2022.p12167
}

\begin{abstract}
A 'fixed film algal photobioreactor (FFAPBR)' was tested forsugar mill effluent (SME) treatment. This reactor was developed in-house using Chlorellavulgaris, an alga, that allowedto grow on weathered rooftop sheet made of Fiber-reinforced plastic (FRP).Experiments carried out in open sun light, in which SME of $80 \mathrm{~L}$, pumped slowly @ $12 \mathrm{~L}^{-1}$ minuteatone end of thereactor, collected at another and re-circulated.To check the effectiveness of the treatment parameters $\mathrm{pH}, \mathrm{COD}$ and $\mathrm{BOD}$ were studied. Reduction in chemical (COD) and biological oxygen demand (BOD) was $>80 \%$ in just $12 \mathrm{~h}$ of treatment.Treated water was diluted in a ratio of 1:1with tap water and tested for fish survival. All fishes survived 96 hours of observation period and beyond.
\end{abstract}

Index Terms- Fixed film algal photo-bioreactor, sugar mill effluent, Chlorellavulgaris, COD and BOD

\section{INTRODUCTION}

$\mathrm{W}$ ater security is one of the major issues discussed at international forum during last few decades. The world is observingincreased demand for freshwater due to population explosionin combination with rapid industrialization and urbanization. Freshwater sources and reserves are finite. Hence, itis imperative to conserve the resource. Recycling of water and reusing wastewater after treatment using environment friendly technologies is one of the prime options to conserve the resource.This is reflecting throughincreased interest observed for reuse of wastewater in agriculture/aquaculture over the last few decades.

According to the notification of Ministry of Environment, Forests and Climate Change (MoEF\&CC, 2016), Government of India, sugar industry is allowed to generate200 L of wastewater per ton of cane crushed. Of these, $100 \mathrm{~L}$ is spray pond overflow or cooling tower blow down and $100 \mathrm{~L}$ is effluent. In Maharashtrastate, cane crushing for the season of 2017-18 was just above 95 million tons (Vasantdada Sugar Institute2018). It means it had produced, approximately 19 million cubic meters (MCM) of wastewater of which $9.5 \mathrm{MCM}$ was sugar mill effluent (SME). This is a huge volume, particularly on a backdrop that large numbers of mills in Maharashtra state of Indialocated in drought prone areas where the annual average rainfall observed around500 to $600 \mathrm{~mm}$.

The present work planned with two objectives; firstly, to treat SME, using fixed film algal photo bio reactor (FFAPBR) and second was to check its effectiveness. Thus, a laboratory scale reactor developed using Chlorella vulgarisspecies. Schematic representation of the research concept is given in figure 1.

\subsection{Rationale for developing fixed film reactor}

The research team working on 'waste to energy' concept for past several years. In early stages of the research, an alga Spirulina was usedfor SME treatment. Spirulina biomass produced in the process was considered as a value added product for e.g. bio-molecule production, biofuels/oil, etc. Most of those experiments were carried out using open type bio-reactors.In the present work, another easily available and commercial species of alga namely Chlorella vulgarisused for SME treatment. Mainly because, a) Chlorella has been used for biofilm formation, to treat dairy wastewater (Johnson and Wen, 2010) and municipal wastewater (Gao et al., 2015) and it is having an ability to consume organic carbon for its growth (Martinez \&Orus 1991, Battah et al. 2013).

This time fixed bio-film reactors (FFAPBR) were used. Following points were considered while designing the experiment.

- In fixed film reactor,alga can grow and produce new biomass using nutrients such as $\mathrm{N}$ and $\mathrm{P}$ from SME i.e. theeffluent 
- A biofilm with alga can provide strong aerobic micro-environment as alga will produce $\mathrm{O} 2$ by photosynthetic process as well as dissolved oxygen from air can help microorganisms to grow faster and degrade any organic matter present in the SME much faster rate.

- Because of fixing the alga as abio-filmthe same biomass will be available for the treatment of SMEcontinuously,for a longer duration; thus treatment time and cost reduction anticipated(Ali et al. 2014)

- Fixed film reactor is helpful for reducing the cost of algal biomass harvesting to a great extent (Christenson and Sims 2012; Ozkan et al. 2012)

From literature survey,it was observed that though Przytocka-Jusiak (1984) reported algal biofilm reactors long back, till today this technology explored to a limited extent. In general, wastewater treatment using algae, often experimented at tertiary treatment level.

Figure 1: Schematic of research concept

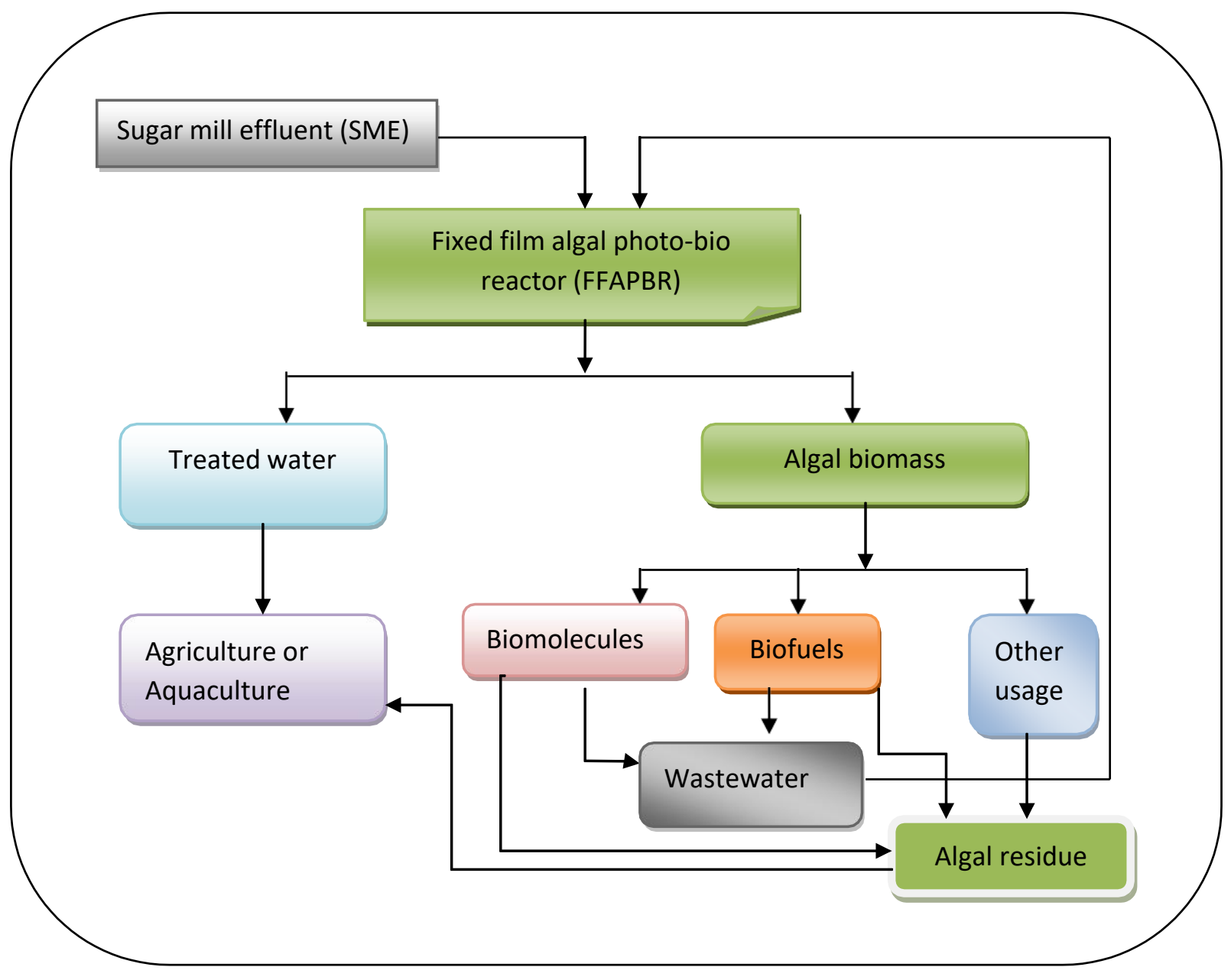

This publication is licensed under Creative Commons Attribution CC BY. 


\section{RESEARCH ELABORATIONS}

Sugar mill effluent (SME), was collected freshly (for each experiment) from sugar mills near to the laboratory. It was subjected to a pre-treatment that involves alum $\left(100 \mathrm{mg}^{-1} \mathrm{~L}\right)$ addition to settle suspended solids. This was done mainly to avoidsettling of particles on algal film and thereby reducing photosynthesis and metabolic activities of the alga.

\subsection{Developing FFAPBR}

This was developed on a laboratory scale by using a weathered roof top sheetof $2 \mathrm{~m}$ in length and $1 \mathrm{~m}$ breadth with $0.4 \mathrm{~cm}$ thickness.Ithadslightly rough surface on ridges and furrows.Corrugated was preferred over plain sheetfor smooth channelization of SME and to avoid its wastage. Culture of Chlorella vulgaris prepared and used by isolating it from a mix culture collected from a water body near to the research laboratory. Initially, this weathered sheet was kept horizontal in shady area, on the terrace of the laboratory. Freshly collected SME was filtered and its $\mathrm{pH}$ was adjusted near to neutral i.e. between 6.8 to 7.2.

Neutralized SME was sprinkled on the reactor sheet, just to make it wet and SMEallowed to accumulate in the furrows of the sheet, for some time. Chlorella culture $(100 \mathrm{ml}$ with cell optical density of $0.912 \pm 0.050$ at $660 \mathrm{~nm}$ ) sprinkled on it three times a day. Afterrepeating this process for about ten days, Chlorella cells got acclimatized to SME and started forming a thin film on the sheet (figure 2). $\mathrm{pH}$ adjustment was done only while developing fixed film. Whereas, in the experiment SME having $\mathrm{pH}$ of $5.3 \pm 0.3$ used directly. In another four days, a distinct film of Chlorella observed on the surface, especially in the furrows of the sheet. This part served as a fixed film algal photo-bioreactor (FFAPBR) for the treatment of SME.

\subsection{The Experiment}

On the day of experiment, this FFAPBR was kept horizontal with gentle slope of $5^{0}$ was maintained for smooth flow. It was exposed to direct sun light. SME was pumped using ordinary submersible pump available in the market(max flow rate @ $18 \mathrm{~L}^{-1}$ minute). In each of the experiment cycle, SME released slowly at $\square 12 \mathrm{~L}$ per minutefrom one end of this reactor through rubber tube having small perforations at a fixed distance so as to coincide with each of the furrow of the reactor. At other end of the reactor, SME was collected in a glass tank and circulated (refer figure 3a and 3b). Total volume of SME used for experiment was $80 \mathrm{~L}$. This treatment was carried out during March-April, which is early summer season in India (average maximum light 59.7 x $10^{3}$ lux and average minimum of $1.5 \times 10^{3}$ lux).The treatment duration was of $12 \mathrm{~h}$ (i.e. $7.00 \mathrm{am}$ to $7.00 \mathrm{pm}$ ). Samples of treated water (of $\sim 120 \mathrm{ml}$ ) collected from the glass tank at every $2 \mathrm{~h}$ interval. Samples centrifuged at 3,500 rpm for 15 minutes and filtered through Whatman's filter paper No. 1. This was mainly to remove the suspended algal cells that would affect COD/BOD. Filtrateused to test $\mathrm{pH}$ and COD levels by following Standard methodspublished by APHA, AWWA and $\operatorname{WEF}\left(22^{\text {nd }}\right.$ edition, 2012). All samples were tested for $\mathrm{BOD}_{3}$ days, using IS 3025 (part 44): 1993. The cycle of experiment repeated twice.

This publication is licensed under Creative Commons Attribution CC BY. 
Few guppy fishes were brought from commercial aquarium near the laboratory, 3-4 days prior to the experiment. Fishes were released into a glass jar containing normal tap water. Air supplied continuously into the water (of glass jar) through aerator commonly used in small aquarium (flow @ approx $3 \mathrm{~L}^{-1}$ minute). Fishfood available in the market fed for 3-4 times in a day. After completion of the experiment related to SME treatment, treated water tested for the survival of these guppy fishes. For this, $250 \mathrm{ml}$ treated effluent was taken in a glass jar after filtering it through Whatman's filter paper No. 1. Treated water taken in the glass jarhad a very light green color due to algal cells/Chlorophyll pigments.It was having COD value between600 - $700 \mathrm{mg} / \mathrm{L}$. According to the effluent discharge norms in India, the COD of outlet should be less than $250 \mathrm{mg}^{-1} \mathrm{~L}$. Therefore, it was decided to dilute the effluent in 1:1 ratio using tap water. The COD of this water (after dilution) was $170 \mathrm{mg}^{-1} \mathrm{~L} \pm 34$. Five fishes were transferred from fresh water jar to the treated water jar using fishing net. Aerator mentioned above was connected to this jar for supply of oxygen. It was observed that, all fishes were acclimatized to treated water in few minutes and survived for $>96 \mathrm{~h}$ comfortably.Regular food was continued in the same manner as prior to release in treated water.
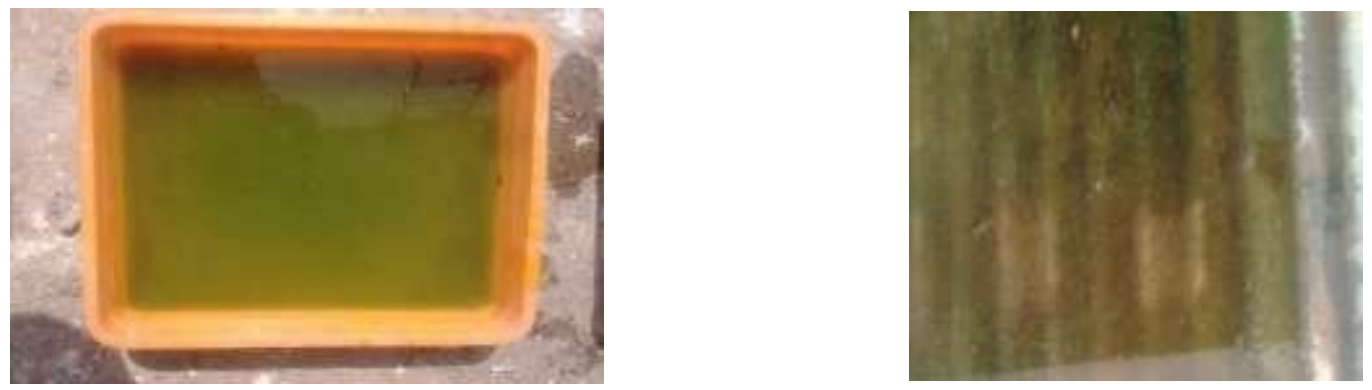

Figure 2: Chlorella culture in a tray and its fixed film developed on the reactor sheet 


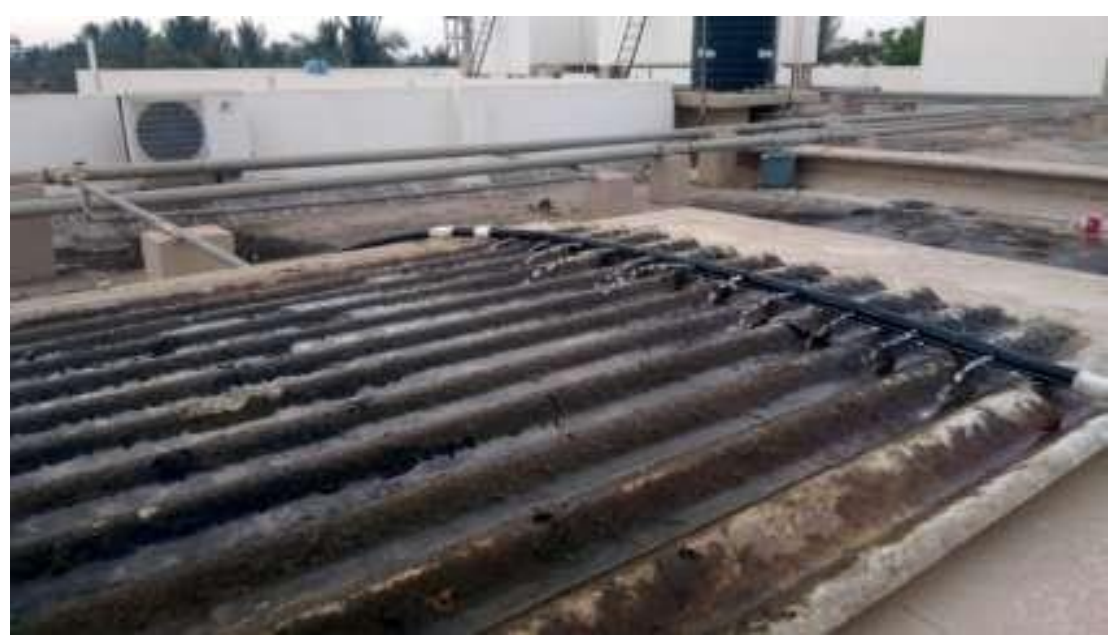

Figure 3a: SME was released on fixed film algal reactor using pump and perforated rubber tube

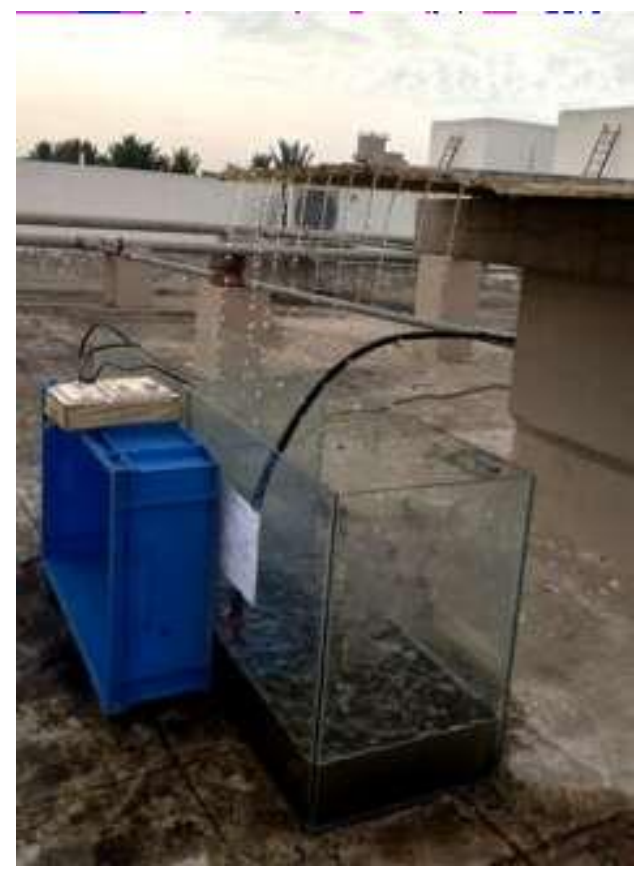

Figure 3b: SME was collected at another end of the reactor and re-pumped 

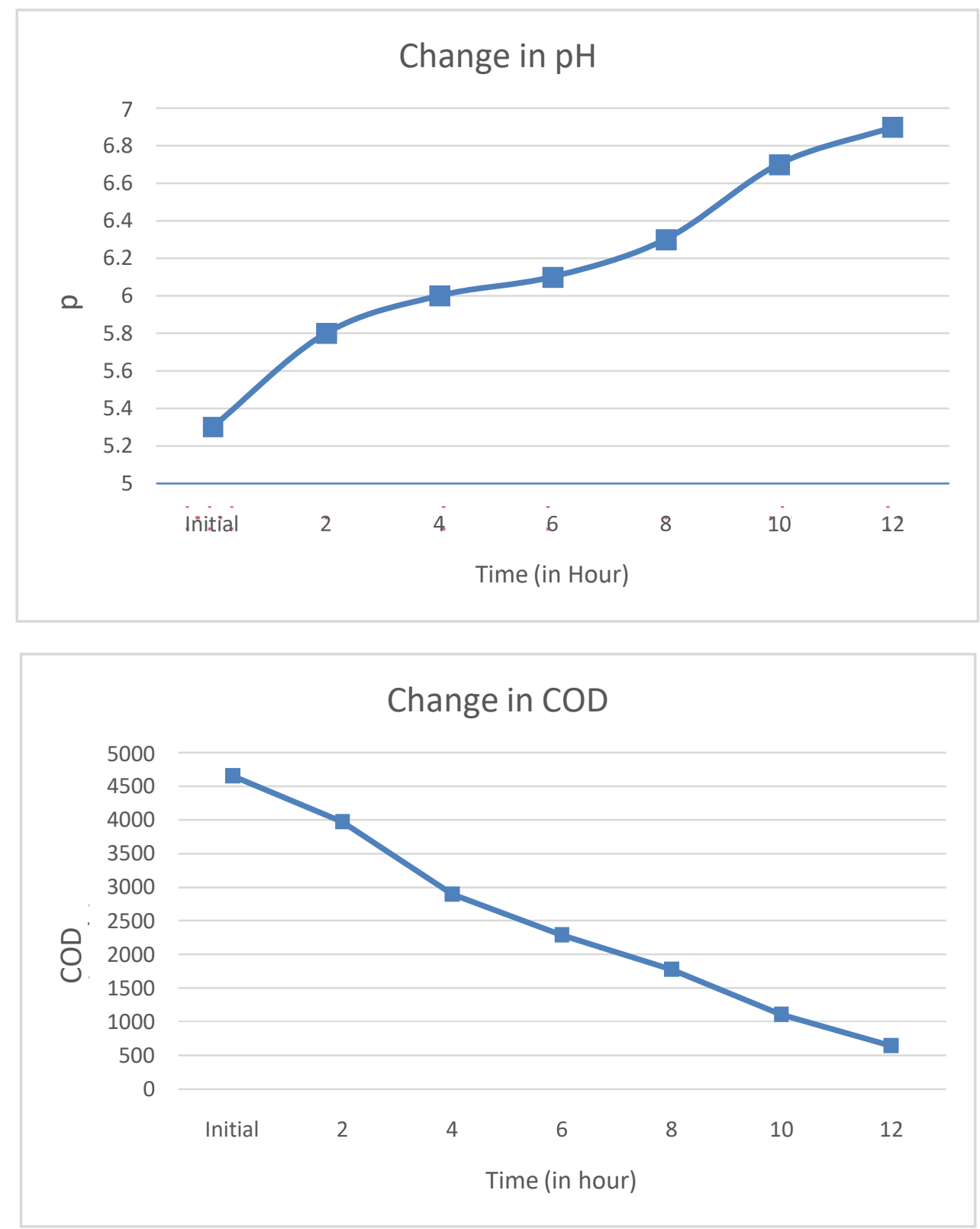


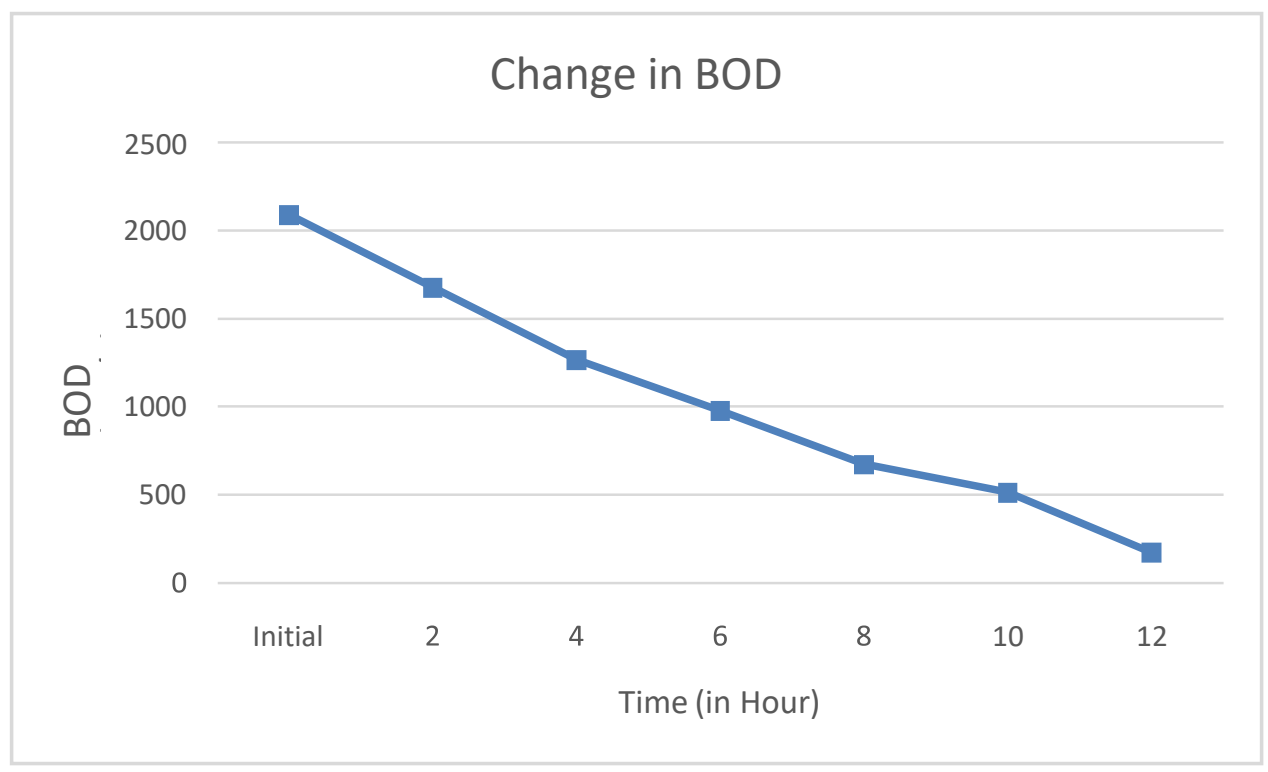

Figure 4: Showing a) change in $\mathrm{pH}$ b) change in COD and c) change in BOD of SME treated using FFAPBR

\section{RESULTS}

As mentioned in the introduction section, prime motive of these experiments was to assess the effectiveness of the FFAPBR treatment for SME and similar strength effluent from non-hazardous units. Therefore, observations of these experiments are highly encouraging and very important to develop the pilot scale treatment plants. Though, the COD of the SME after $12 \mathrm{~h}$ treatment was not within the standard prescribed by the regulatory authorities (i.e. $<250 \mathrm{mg}^{-1} \mathrm{~L}$ ), it reduced considerably by approx. 85\% (from 4,560 to $663 \mathrm{mg}^{-1} \mathrm{~L}$ - please refer figure $4 \mathrm{~b}$ ).Also, BOD reduced by approx. $91 \%$ in this $12 \mathrm{~h}$ treatment (fig. $4 \mathrm{c}$ ). This is a good achievement for treatment of a high COD strength effluent. Hammouda et al. (2015) used Chlorella species to treat a mixture of domestic and industrial wastewater having initial COD of $627 \mathrm{mg}^{-1} \mathrm{~L}$. They used Chlorella culture in suspended form and observed COD reduction of $81.1 \%$ in 20 days. Whereas, Chlorella conglomerata used by Sivasubramanian et al. (2012) of for the treatment of wastewater from soft drink industry, observed COD reduction of $77 \%$ (initial COD of $998 \mathrm{mg}^{-1} \mathrm{~L}$ ), in 10 days of treatment.In a batch mode laboratory experiment,Elumalai et al. (2014) have reported a maximum of $94 \%$ reduction in COD after 21 days of incubation with a consortium of Chlorella vulgaris and Scenedesmusobliqus. This research team had carried out SME treatment using Spirulina in simple open photo-bioreactors (PBR).

Algal cultureobserved suspended in such PBR. In those experiments, 96 to $120 \mathrm{~h}$ treatment time utilized to achieve nearly same percent of COD reduction(Deshmane et al. 2016). Thus, the treatment efficiency of FFAPBR observed much higher compared to treatment through suspended algae culture of open PBR (table 1). 
Table 1: Comparison of treatment efficiency considering COD as a base parameter for FFAPBR and open type of reactor

\begin{tabular}{|l|l|l|l|l|}
\hline Reactor type & \multicolumn{2}{|l|}{ COD $(\mathrm{mg} / \mathrm{L})$} & $\begin{array}{l}\text { Treatment time } \\
\text { (in hour) }\end{array}$ & $\begin{array}{l}\text { COD reduction } \\
\text { (in \%) }\end{array}$ \\
\hline & Initial & Final & & \\
\hline FFAPBR & $4560 \pm 92$ & $\begin{array}{l}663 \\
\pm 48\end{array}$ & 12 & 85.5 \\
\hline Open photo-bioreactor & $\begin{array}{l}2310 \\
\pm 57\end{array}$ & $\begin{array}{l}195 \\
\pm 31\end{array}$ & $96-120$ & 91.6 \\
\hline
\end{tabular}

According to Chan et al. (2009), anaerobic systems become favorable for the treatment of higher strength wastewater (biodegradable COD concentration over $4,000 \mathrm{mg}^{-1} \mathrm{~L}$ ). But, in the present work, FFAPBR was used at secondary treatment stage for SME having COD up to $4,600 \mathrm{mg}^{-1} \mathrm{~L}$. Thus, effectiveness of the treatment for such high strength wastewater was tested and such treatment observed feasible. This treatment also helped in shifting the acidic $\mathrm{pH}$ to near neutral without addition of any chemicals (fig. 4a). Such increase in the $\mathrm{pH}$ of the medium is reported earlier by few researchers (Kalubowila et al. 2013; Velichkova et al. 2014; Hammouda et al. 2015).

Another objective of testing feasibility of use of treated SME for agricultural or aquaculture activities was also successful. In the simple bio-assay, when the treated water was diluted in a ratio 1:1 using tap water, all five fishes observed alive and normal in their activities after $96 \mathrm{~h}$ observation time (refer figure 6).

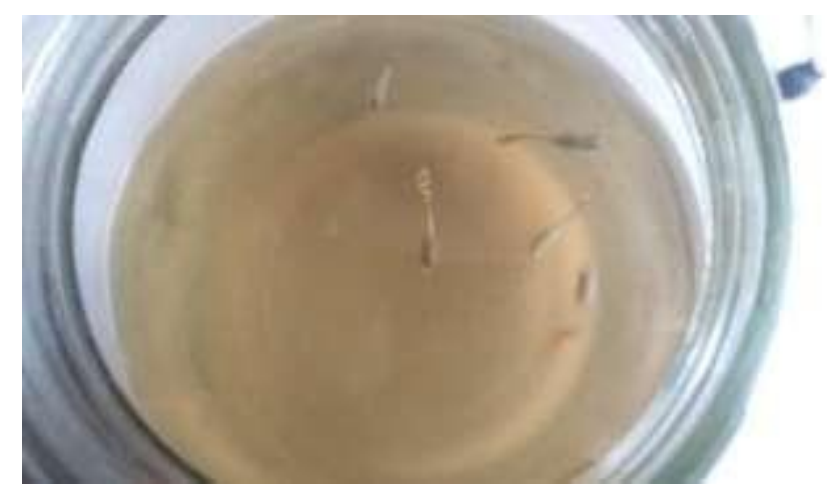

Figure 6: All five fishes were alive and stable after $96 \mathrm{~h}$ exposure to treated SME (diluted in a ratio 1:1)

Not a single mortality observed.Thus, the concept of reusing treated water (SME) for productive activity seems to be feasible. Domestic wastewater fed aquaculture is more common in developed as well as developing countries. Such activity can be feasible using SME. It has good potential to generate 
employment at local level. Toxicity tests and health related issues for using the fish as a food need to be checked in detail before developing this use at commercial scale.Other major observations includes-

- Odour of SME reduced significantly after the treatment

- In this experiment, $15 \%$ (i.e. $~ 12 \mathrm{~L}$ ) evaporation rate of SME was observed for $12 \mathrm{~h}$ treatment time during bright sunny day of Indian early summer. Gross et al. (2015) has reported cumulative water loss of $10 \mathrm{~L}^{-1} \mathrm{~m} 2$ for their experiment using trough based rotating algal bioreactor.

- Though, Chlorella used in developing fixed film, but the reactor was kept in open environment. Hence, contamination of other species to minor extent was observed. Such contamination is difficult to control or avoid in natural environment. Hence, accepted and considered as an integral part of the experiment.

Overall, the technology appears to be effective in converting waste (SME) into biomass (algal as well as fish). Treated water as well as algae produced during the treatment can be utilized for fish biomass. Thus, secondary employment, particularly for rural population residing in the nearby areas of the sugar mill is feasible trough thepresent technology.

Overall, the experimented technology is-

1) Simple, less expensive option for developing FFAPBR,

2) Significant in reducing important pollution parameter i.e. COD and BOD

3) Suitable for achieving effluent treatment having COD up to $5,000 \mathrm{mg}^{-1} \mathrm{~L}$,

4) An easy option of producing algal biomass and use it as a resource (for biofuels/biomolecule production)

5) less expensive or cost saving on harvesting algal biomass from the surface of the reactor either manually or mechanically

6) Useful in reusing treated water safely for agriculture and/or agro-based activity of aquaculture

7) having great potential for sustainable employment development in rural areas

These experiments performed at labscale, more or less in controlled manner. However, while scaling up the technology, following limitation anticipatedbased on the experimental observations.

- Seasonal variation in temperature may affect the algal growth and thereby effectiveness of the treatmentbut Such variations can be overcome by using artificial light arrangement to some extent

- Overall, the assembling of the setup (of FFAPBR) need to be designed carefully while scaling up the technology for treating voluminous effluent

- In this experiment, only fish survival test wascarried out; study on toxicity, healthiness and biochemical aspects of fish may be consideredbefore using treated water for aquaculture practices

- Most importantly, economics and energy footprints of the treatment need to be re-checked at upgraded scale

\section{CONCLUSION}

The experiments and results show that, FFAPBR developed using Chlorella is having a great potential to treat wastewater of high organic strength (in terms of COD level upto $5,000 \mathrm{mg}^{-1} \mathrm{~L}$ ). Treatment time of just $12 \mathrm{~h}$ to reduce the COD by $85 \%$ and BOD by $91 \%$ suggests competitiveness of FFAPBR with prevailing electro-mechanized effluent treatment systems such as activated sludge process. Fish survival test denotes SME could serve as a valuable resource for aquaculture; also indicate the suitability, Eco friendliness and safe nature of FFAPBR treatment process. Thus, integration of water conservation with employment for sustainable development could be feasible using this technology.

\section{ACKNOWLEDGEMENT}

The authors are thankful to The Director General, Vasantdada Sugar Institute, Pune for his encouragement for this research work and Shreenath Mhaskoba Sakhar Karkhana Limited, Pune for providing SME.

\section{REFERENCES}

[1] Ali Inaam, N., Hussein, A.,Sabtie Khalid, F., Hassan Shaima, F.,Amal, H.,Hmood Saba, H. Ubeed. (2014).Moving bed biofilm reactor technology as batch system in wastewater treatment. Journal of Biotechnology Research Center (Special edition), 8, 66-75.

[2] APHA. (2012). Standard methods for the examination of water and wastewater, 22nd edition edited by E. W. Rice, R. B. Baird, A. D. Eaton and L. S. Clesceri. American Public Health Association (APHA), American Water Works Association (AWWA) and Water Environment Federation (WEF), Washington, D.C., USA. This publication is licensed under Creative Commons Attribution CC BY. 
ISSN 2250-3153

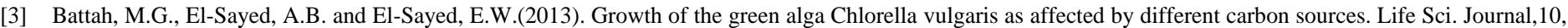
2075-2081.

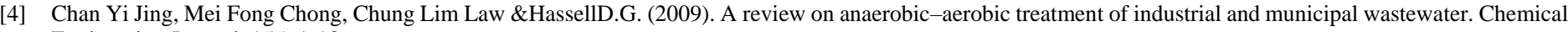
Engineering Journal, 155, 1-18.

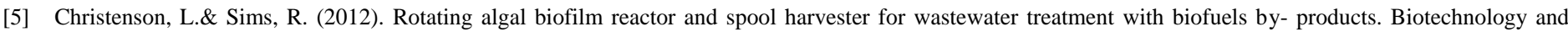
bioengineering, 109, 1674-84.

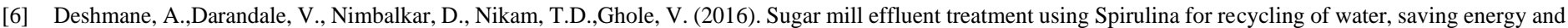
producing protein. International Journal of Environmental Science and Technology 13, 749- 754.

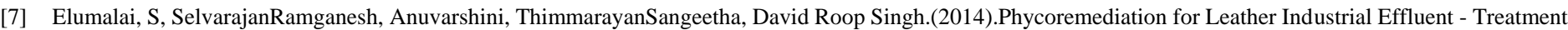
and Recycling Using Green Microalgae and its Consortia. InternationalJournal of Current Biotechnology, 2, 1-9.

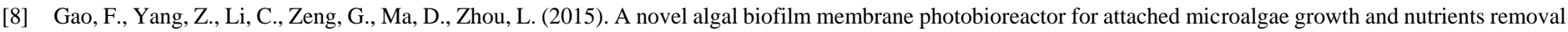
from secondary effluent. Bioresource Technology, 179, 8-12.

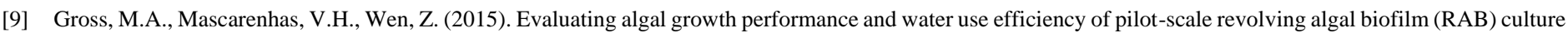
systems. Biotechnology and bioengineering, 112, 2040-50.

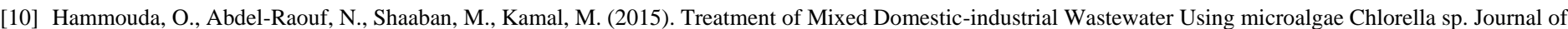
American Science, 11, 303-315.

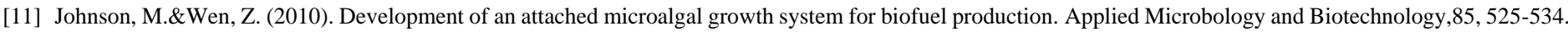

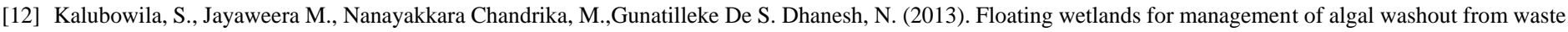
stabilization pond effluent: case study at Hikkaduwa waste stabilization ponds. Engineer,Vol. XXXXVI, No. 04, 63-74.

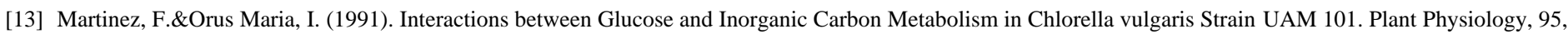
1150-1155.

[14] Ministry of Environment, Forests and Climate Change. Government of India. (2016).Notification GSR 35 (E) dated 14.01.2016.

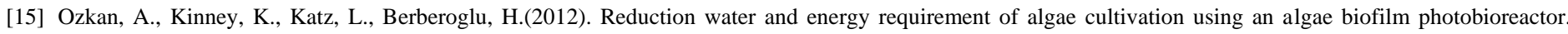
Bioresource Technology, 114, 542-548.

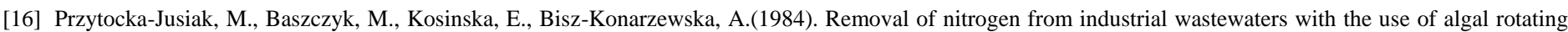
disks and denitrification packed bed reactor. Water Research, 18, 1077-1082.

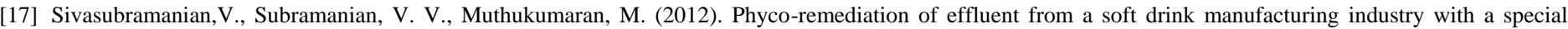
emphasis on nutrient removal - a laboratory study. Journal of Algal Biomass and utilization, 3, 21- 29.

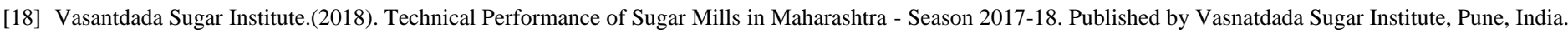
ISBN 978-81-934198-3-0.

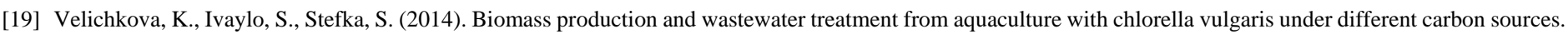
Scientific Bulletin Series Food Biotechnologies, XVIII, 83-88.

\section{AUTHORS}

First Author - Dr. Amol B. Deshmane,Department of Environmental Sciences, Vasantdada Sugar Institute, Pune, Maharashtra 412 307 India. Telephone: +91 20 26902347; Email: amoldeshmane.vsi@ gmail.com

Second Author - Vishal P. Jadhav, Department of Environmental Sciences, Vasantdada Sugar Institute, Pune, Maharashtra 412307 India. Email: vishalpjadhav1995@gmail.com

Third Author - Dr. Vikram S. Ghole, Executive Director, Lokmanya Medical Research Center, Chinchwad, Pune 411033. Tele/fax: +919403186313, email: gholevs@yahoo.com 